\title{
Academic Library Services in Virtual Worlds: An Examination of the Potential for Library Services in Immersive Environments
}

\author{
Jenna Ryan and Marjorie Porter \\ Louisiana State University \\ Baton Rouge, LA, USA
}

\author{
iryan1@Isu.edu; eiroj2@lsu.edu
}

\author{
Rebecca Miller \\ Virginia Polytechnic Institute \\ and State University \\ Blacksburg, VA, USA
}

millerrk@vt.edu

\section{Executive Summary}

Current literature on libraries is abundant with articles about the uses and the potential of new interactive communication technology, including Web 2.0 tools. Recently, the advent and use of virtual worlds have received top billing in these works. Many library institutions are exploring these virtual environments; this exploration and the enthusiasm it has generated led to our library's interest in developing library content in a virtual world.

EDUCAUSE Learning Initiative defines a "virtual world" as "an online environment whose "residents' are avatars representing individuals participating online" (EDUCAUSE Learning Initiative, 2006, p. 1). Virtual worlds may also be described as "virtual communities" or "virtual environments" (Porter, 2004). In higher education, terms such as "virtual campuses," "cooperative learning ecosystems," and "virtual research environments" are also used to describe the virtual world concept (Cartelli, et al., 2008; Galarneau, 2009; Sonnenwald, et al., 2009). Virtual worlds grew out of the world of computer gaming, in which MMORPGs (Massive Multi-Player Online Role Playing Games) have used such software to provide an immersive, interactive gaming experience. Where virtual worlds differ from MMORPGs is in the lack of any defined goal or quest. A virtual world is more of a social environment than a game, and as such is a logical extension of social networking software such as instant messaging. Theoretically, one can reproduce almost any real life activity within the virtual world - including library services and higher education.

As early career librarians, the authors of this article are all members of the reference department at the main research library. All three authors are tenure-track library faculty who are experienced users of communication and web technology, are not intimidated by new software, and are thus more likely than not to explore new technology. When approached about the possibility of

Material published as part of this publication, either on-line or in print, is copyrighted by the Informing Science Institute. Permission to make digital or paper copy of part or all of these works for personal or classroom use is granted without fee provided that the copies are not made or distributed for profit or commercial advantage AND that copies 1) bear this notice in full and 2) give the full citation on the first page. It is permissible to abstract these works so long as credit is given. To copy in all other cases or to republish or to post on a server or to redistribute to lists requires specific permission and payment of a fee. Contact Publisher@InformingScience.org to request redistribution permission. adding content to an already-established university site in Second Life, we decided that we first needed to address the all-important underlying question: How will a virtual world help us, as an academic library, accomplish our purpose? As we set out to answer this question, we found that all is not perfect inworld. 
Virtual world environments are not particularly easy to use and, once established, do not necessarily accomplish the desired goals. On the other hand not all difficulties that accompany libraries in virtual worlds lie within the virtual world itself. A virtual presence requires a significant real world commitment. In order to assess the usefulness of virtual environments, we examined some of the traditional services offered by libraries and determined what would be required in order to re-create that service in a virtual world. We then examined three virtual world programs, including Second Life, to determine if they provided what was needed in order to offer the library service. What we discovered has made us rethink what we hoped to add to our existing university space in Second Life and what direction we should go in terms of new technology.

Keywords: Virtual Worlds, Immersive Environments, Libraries, Library Services

\section{Review of Literature}

In addition to creating a loud buzz among librarians at conferences and in staff meetings, topics related to virtual reality in higher education have exploded onto the current library literature landscape over the past several years. Research revolving around online social media such as blogs, wikis, and networking sites has gained a strong foothold in recent library literature; however, one specific issue within this category of literature grips the library world like no other: Second Life. Second Life remains an area of such fascination in the world of library and information science that it has gained its own LC (Library of Congress) subject heading and represents the central focus of most of the library literature published on virtual worlds and related technologies since 2006. Many publications discussing research into virtual worlds refer to a statistic from the Gartner Group suggesting that by the year 2011 more than 80 percent of "active Internet users" will be involved with some sort of virtual world community (L. Bell \& Trueman, 2008; Dell, 2007; Gartner, 2007; Jarmon, Traphagan, Mayrath, \& Trivedi, 2009; Jennings \& Collins, 2007). Each time it appears in a publication, this statistic is used as support for various institutions' decisions to become involved in virtual worlds. Although the Gartner report does not functionally define "active Internet users," it does go on to clearly state that groups and people interested in working with virtual worlds "should experiment with virtual worlds, but not plan massive projects" in any single virtual world, as the entire platform is still in the process of stabilizing (Gartner, 2007). Across the disciplines most heavily invested in virtual worlds - business and educationgenerally, this recommendation has not been incorporated into the virtual world research and the literature that has come out of it.

Across disciplines, researchers interested in the potential of virtual worlds tend to concentrate their investigations and explorations on Second Life. Notable exceptions to this focus on Second Life can be found in research conducted by Paul Messinger and his colleagues as they developed a comprehensive history of virtual worlds and the wide variety of virtual worlds in existence (Messinger, et al., 2009). Similarly, Sarah de Freitas and her co-researchers put together an evaluation methodology to examine learning experiences in more than 80 unique virtual worlds (de Freitas, et al., 2009). For the most part, though, other studies lightly touch on the existence of other virtual worlds as alternatives to Second Life (Boxen, 2008; EDUCAUSE, 2007; Erdman, 2007; Gilson, 2007; Salmon \& Hawkridge, 2009; Sonnenwald, et al., 2009). Stephen Abram, in his Foreword to Virtual Worlds, Real Libraries, briefly talks about an employer that had previously "invested sponsorships and effort" into two other virtual worlds: Active Worlds and There.com, which has since closed its doors (2008, p. xi). Other exceptions to the Second Lifecentric attitude in the literature appear in Virtual Worlds, Real Libraries, including the group at Appalachian State University that selected Active Worlds as the first virtual world to host distance learning instruction in 2004 and Marty Grover's comparisons of virtual worlds for child and teen projects (Grover, 2008; Purpur \& Ochoa, 2008). 
A. J. Kelton, however, provides insight into the nature of the literature when he describes how Active Worlds, launched in 1997, has faded into obscurity because of the "mass cultural appeal of Second Life," which launched in 2003 (2008, p. 15). That most researchers have devoted their time and energies to exploring Second Life rather than comparing the benefits of various virtual worlds seems to be an effect of Second Life's "mass cultural appeal." An overview of crossdisciplinary literature on virtual worlds reveals a need to examine the potential of other virtual worlds.

Second Life is unquestionably the most prominent virtual world in the body of literature dealing with immersive environments. Many researchers claim that it is the most popular virtual world, using Second Life's total number of registered users as support for this claim. Steven Warburton, for example, asserts that Second Life "represents the most mature of the social virtual world platforms," offering as evidence the "high usage figures" of Second Life (2009, p. 416). While various Second Life usage numbers have been reported, users' actual, ongoing involvement with the virtual world remains somewhat disputed. Recent statistics suggest that the number of registered users with Second Life is just short of 20 million (Second Life, 2010e); however, the number of active users within Second Life may be well below this number (Middleton, 2009). Kristin Demetrious writes that "Second Life's high potential for marketing to a large audience is itself an object of marketing," and reports that " $85 \%$ of its users do not pursue any meaningful long-term involvement with the program." (2008, p. 2)

Despite the confusion over specifics surrounding the usage of Second Life, this virtual world remains the most frequently studied and explored virtual world, especially in the realm of education. In his article for the recent virtual world-themed issue of British Journal of Educational Technology, Warburton indicates that Second Life represents the "most attractive proposition for educators" because of its "relatively low cost of entry, ability to create complex objects, and sophistication of graphics." (2009, p. 418) Regardless of the veracity of Warburton's reasoning for the popularity of Second Life among educators, he remains absolutely correct that Second Life undoubtedly represents the most widely used virtual world platform within higher education; most of the institutions involved in Second Life have, at minimum, established virtual campuses (De Lucia, Francese, Passero, \& Tortora, 2009; Jennings \& Collins, 2007; Kattelman, 2008; Purpur \& Ochoa, 2008).

Universities and colleges have also used the virtual world platform for a variety of different functions including field trips, distance education, collaborative class projects, laboratories, and the overall enhancement of curriculum with a 3-D immersive environment. A recent pilot study showed that "Second Life can facilitate social presence and foster socialization among distance learners." (Edirisingha, Nie, Pluciennik, \& Young, 2009, p. 459) Ben Kattelman specifically mentions Second Life as a virtual world with the potential to assist people with "limited mobility" in walking around a college campus $(2008$, p. 614). Learning through "role play" is the subject of Peter Twining's research on using Second Life to encourage a "lived experience" of learning through scenarios that instructors set up specifically for students, while other educators use Second Life as a tool for students to explore virtual landscapes by building objects or through "skills challenges." (Sanchez, 2009; Twining, 2009) Finally, Second Life offers still other educators a platform for allowing their students to experience something they could not in real life, such as the Media Zoo at the University of Leicester or the simulation of a film studio at Birmingham City University (Foss, 2009; Wheeler, 2009).

As parts of educational communities, especially on the university level, libraries have been investigating various applications of the virtual world platform since 2006. Library literature's fascination with virtual worlds, specifically Second Life, can be attributed to the efforts of the Alliance Library System. The Alliance Library System is a "multitype library system" in Illinois, and has been a fundamental player in getting libraries involved in and enthusiastic about Second Life 
(Alliance Library System [ALS], 2010). Lori Bell and Rhonda Trueman write in the Introduction to their Virtual Worlds, Real Libraries that when the Alliance Library System first launched its presence in Second Life in April 2006, "there was only one small library in SL and a couple of projects in Active Worlds" (2008, p. xvii). Bell and Trueman also note that "although the presence of libraries in all virtual worlds has been increasing steadily, most activity currently takes place in SL" (2008, p. xvii). Since the 2006 launch of the Alliance Virtual Library, the institution has expanded into the Info Archipelago, which incorporates over 40 different areas of Second Life that are devoted to library and information services.

The Info Archipelago functions as a public library serving the Second Life community. According to an early article written by the Alliance Virtual Library's founders, the Library "offers reference services...but also receives questions about Second Life, Info Island, and how to find information" within Second Life (L. Bell, Peters, \& Pope, 2007, p. 14). Most of the literature devoted to libraries in Second Life, however, describes attempts of real-world libraries to use the virtual world platform to enhance or extend the services already offered within by the real-world library institution. Many libraries view virtual worlds as the ideal tool for enhancing reference services and offering another access point to a library's collections. Jacquelyn Erdman points to Second Life as a new access point to reference services for a library's pre-existing user base, as well as for virtual world citizens who do not already have a "home" library (2007, p. 31). Similarly, guest editors in a recent Reference \& User Services Quarterly column remark on the benefits of a virtual world's potential to offer extra support to the faculty and staff, while also offering a visual enhancement to a basic text chat or discussion board reference exchange (Ford, Gerardin, Yamamoto, \& Gordon, 2008, p. 325). Altogether, many library researchers ponder the role of virtual worlds in enhancing reference services (Mathews, 2007; Thompson, 2009).

Aside from the extra access point that virtual worlds can offer existing library institutions, virtual worlds often appear as outreach tools within the literature. In virtual worlds libraries have the option to build special exhibits and host special events in a virtual world that would be impossible in reality. Lori Bell, Kitty Pope, and Tom Peters, all associated with the Alliance Virtual Library in Second Life, mention multiple examples of this type of outreach in their publications (2007, 2008). Other examples of special exhibits and events dominate the library literature and seem to be the most popular form of library involvement in Second Life (Floyd, Frank, McOok, \& Smith, 2007; Ford, et al., 2008; Greenhill, 2008; Pierce, 2009). Library literature also shows that many libraries are attempting to use virtual worlds as instructional tools. Lili Luo and Jeremy Kemp (2008) explore the application of Second Life to information literacy instruction, asserting that Second Life's "spatial simulation of the real world can be fully explored to organize engaging activities such as games to appeal to undergraduate students' interests." However, the majority of library or information literacy instruction that occurs within virtual worlds does so in the form of tutorials or learning modules using presentation software and the new media available in virtual worlds (Floyd et al., 2007, p. 5).

Finally, a number of articles are devoted to the use of virtual worlds as a tool for professional development, collaboration, and communication among those within the library profession. Jill Hurst-Wahl mentions "networking" as one of the primary activities in which librarians participate in Second Life; specifically, she writes that librarians have "found the solution to real-world problems through SL networks" by allowing librarians to collaborate and communicate in a way that is "not constrained by location or existing relationships" (2007, p. 36). An interesting example of this sort of use of Second Life is described by Kathryn Greenhill, an Australian librarian. Greenhill worked on the Australian Libraries Building in Second Life, a project which ultimately connected Australian librarians with a large group of international librarians via the virtual world and helped break down the "professional isolation" that many librarians were experiencing (2008, p. 381). Similarly, researchers participating in the 2009 Joint Conference on Digital Libraries in 
Austin, Texas, developed a virtual poster session held in Second Life (Lee, et al., 2009). Noting that the virtual poster session could benefit poster presenters, conference attendees, and other people in Second Life who may be interested, the researchers aimed to support "researchers and educators, well into the future," by improving "collaborative team work in Second Life" (Lee, et al., 2009, p. 473).

It must be noted that a smaller, although significant, portion of the literature about Second Life focuses on Second Life as a community ripe for sociological study. No such studies have been undertaken in any of the other prominent virtual worlds, so the research revolving around virtual communities relates directly to Second Life. Not surprisingly, these studies underscore a variety of issues that are cause for real concern when considering the appropriateness of Second Life in education. Studies focusing on sexual identities within Second Life highlight the "objectification" and "marginalization" of members of the Second Life community (Brookey \& Cannon, 2009 , p. 145). Other studies highlight the high levels of violence and harassment, such as "virtual rape" and other "predatory" acts that exist within Second Life (Tennesen, 2009). Indeed, researchers specifically note that "boundaries between controlled educational spaces and sexualized content in Second Life can be blurry" (deWinter \& Vie, 2008), an issue relevant to the educational world that Michael Bugeja alludes to when he wonders who will be "held accountable for requiring students to enter a virtual world filled with online harassers" ( Bugeja, 2007, p. 18).

Similarly, David Bell underscores another potential area of risk within Second Life, noting that it is essential to understand "how economic, social, and cultural value" operate in Second Life, since the capitalist economy that holds Second Life together "has profound implications for learning." (2009, p. 516) Bell makes it clear that the capitalist environment of Second Life, in particular, may affect educators more than they would think or even notice at the outset. Unfortunately, there is no reference point for the level of violence, harassment, and economic effects within virtual worlds that are not Second Life, although the assumption that other worlds hold the same risks clearly exists.

The literature devoted to virtual worlds in higher education, both ubiquitous and compelling, is hardly conclusive or even very diverse. Researchers and authors generalize their experiences in Second Life to the entire scope of virtual worlds, foregoing critical comparisons of the benefits, issues, and suitability of Second Life with those of other virtual worlds. More than anything else, researchers tend to highlight the potential of virtual worlds without substantiating how the potential might be fulfilled. While Hurst-Wahl's assessment that librarians are "positioning themselves for the tools, services, and user environments" that may come after Second Life (2007, p. 53) represents an insightful view of libraries' participation in Second Life, there nevertheless remains the disturbing impression that Second Life's Wild West-like boom has already spawned a collection of ghost town campuses and institutions. Without a real, purposeful analysis of why various institutions want to use virtual worlds and how they plan to accomplish their goals, the entire project seems fated for gradual collapse, as Jennifer Pierce notes when she suggests that campuses merely replicating real life services and spaces are vacant from visitors $(2009$, p. 61). Although Pierce specifically opines that gaming in virtual worlds might be the venture that users might find appealing, she broaches a much bigger concept overall: that any institution considering a virtual platform needs to reflect on both their community and their final goal of virtual existence in deciding how, and where, to proceed with building a presence in a virtual world.

Recent literature includes several examples of thoughtful analysis revolving around the evaluation and assessment of virtual worlds as tools for use in education, business, and other related areas. The earliest example of this type of assessment appears in a 2004 issue of the Journal of Computer Mediated Communication. Constance Porter examined "virtual communities" through a five-pronged approach that includes an examination of the purpose, place, platform, population, and profit model of various virtual communities (Porter, 2004). Messinger and his colleagues 
took this approach a bit further in 2009 by refining the typology developed by Porter to reflect qualities of the numerous virtual worlds that this group identified (Messinger, et al., p. 206). Along the same lines, Antonio Cartelli and his co-researchers developed a virtual world evaluation model that focused on five areas: organizational issues, technological issues, pedagogical issues financial issues, and consolidation issues (Cartelli, et al., 2008, p. 124-125). Groups utilizing these and other virtual world assessment tools generally find that other tools meet their needs in a more efficient and secure manner. Doug Vogel and his group of researchers, for example, used similar assessment techniques to compare Second Life other "group support technologies" (Vogel, Guo, Zhou, Tian, \& Zhang, 2008, p. 11). This toolbox of email, forums, videoconferencing, and MSN compared favorably to Second Life, ultimately illustrating that Second Life was less useful and more problematic than any of the other technologies examined by the researchers (Vogel, et al., 2008, p. 16). Overall, this type of critical assessment has not yet appeared within library literature. The study that follows attempts to fill this gap by thoughtfully examining the potential value of virtual world software in the library environment.

\section{Library Services}

Although our university already had a site in Second Life we felt we should consider all possibilities to best use our time and resources. We decided to examine several different virtual world platforms to determine which one(s) might actually meet the library's needs. As we examined the literature, we found several questions that were not satisfactorily answered. These included questions such as: who is currently using virtual worlds and why? What are the hardware requirements? Are our users likely to have the needed hardware and software capabilities or do we need to supply them? What kind of skills do we need to create content in-world? What kind of content works well? What kinds of risks are associated with virtual worlds and how do we guard against them? And, importantly, is Second Life the best place to build?

For an examination of these virtual platforms we began by establishing our in-world goals. We established a list of library services which we would want to develop in-world, including Reference Services, Collection Access, Exhibits and Outreach, and Instruction. We then examined these services, investigating the requirements for them to be functional in a virtual environment.

\section{Virtual World Evaluations}

Having established our goals, our next task was to determine whether the service goals of the library could be met within virtual worlds. To do this we examined three different virtual worlds using a list of criteria. Ultimately, we were able to offer an objective portrait of each virtual world. We selected worlds that were 3D and allowed the user to create content. We excluded any virtual world that did not allow substantial user content, such as Gaia Online. Additionally, we excluded any virtual world that could be considered a Role Playing Game (RPG) such as World of Warcraft, Sims Online, or EverQuest. Unlike RPGs, in which the user's role is static and defined by quest objectives, social virtual worlds provide what is essentially a stage or a platform allowing users to interact in self-defined ways. We also excluded virtual worlds that required a substantial amount of user programming knowledge such as OpenSim and Multiverse; these worlds should be considered by any organization that does have the programming resources available.

The virtual worlds we examined are Second Life, Openlife Grid, and Active Worlds. All of these worlds required that client software be downloaded and have particular hardware and operating system requirements. Not all of them will run on all of the three major operating systems (Windows, Mac OS X, and Linux). Library users would need a place to access these virtual worlds. 
Once we determined which virtual worlds to evaluate, we developed the evaluation criteria. We proceeded with our evaluations with a set of assumptions. We assume that a computer lab with the requisite hardware, software, and update schedule would be available to students. We assume interest in re-creating certain established library functions in the virtual world, not in creating new functions because we are in a virtual world. Lastly, we assume that we have, as any particular academic library has, a healthy mix of librarians with varying degrees of technological ability and interest in virtual environments.

We created an account with each virtual world and all three authors separately evaluated each virtual world using the same criteria. Some of the criteria, such as cost and technical requirements, were objective in nature. Others, such as ease of use and analysis of risk, were subjective. After each author had completed the evaluation form, we compared the subjective evaluations and summarized the main points. The evaluation criteria are as follows:

- Cost, including individual memberships and purchasing and maintaining a site

- Technical requirements and support

- Ease of using the virtual world -- including how to navigate, communicate, types of activities, and how to interact with virtual objects

- Creating content

- An analysis of risk

\section{Cost}

When considering cost it is important to remember that all of these virtual worlds are commercial enterprises rather than non-profit or educational institutions. They do not share a common purpose or mission with academic libraries, although they are happy to sell space and access to universities. In fact, the primary source of revenue for all of the virtual worlds is the sale of virtual land which translates to server space in the real world (Sbrunozzi, 2008). The virtual world service provider profits and virtual world economies are based on land sales. Libraries should expect to pay for virtual space and, in some virtual worlds, for individual memberships. All of the virtual worlds provide a free basic membership and premium memberships which expand the capabilities of the user in-world. Membership does not include in-world money, which is purchased separately. All of the virtual worlds have some kind of currency, which can be bought for real money with an exchange rate that fluctuates. See Table 1 for a detailed membership and currency comparison among the three virtual worlds.

Table 1: Membership and Exchange Information

\begin{tabular}{|c|c|c|c|}
\hline & Membership & $\begin{array}{c}\text { Membership } \\
\text { Cost }\end{array}$ & $\begin{array}{c}\text { Virtual World } \\
\text { Currency } \\
\text { Exchange } \\
\text { (November 2010) }\end{array}$ \\
\hline $\begin{array}{l}\text { Second } \\
\text { Life }\end{array}$ & $\begin{array}{l}\text { Basic- includes customizable avatar } \\
\text { and basic inventory, option to cre- } \\
\text { ate objects, option to buy and sell } \\
\text { and rent space from other users. } \\
\text { Premium- option to buy land, ex- } \\
\text { panded technical help from Linden } \\
\text { Labs, given a Linden Dollar allow- } \\
\text { ance (Second Life, 2010a) }\end{array}$ & $\begin{array}{l}\text { Basic- free } \\
\text { Premium- USD } \\
\$ 9.95 \text { per } \\
\text { month (Second } \\
\text { Life, 2010h) }\end{array}$ & $\begin{array}{l}\text { USD } \$ 1 \text { to L } \$ 255 \\
\text { (Second Life, } \\
2010 \text { b) }\end{array}$ \\
\hline
\end{tabular}




\begin{tabular}{|c|c|c|c|}
\hline & Membership & $\begin{array}{c}\text { Membership } \\
\text { Cost }\end{array}$ & $\begin{array}{c}\text { Virtual World } \\
\text { Currency } \\
\text { Exchange } \\
\text { (November 2010) } \\
\end{array}$ \\
\hline $\begin{array}{c}\text { Active } \\
\text { Worlds }\end{array}$ & $\begin{array}{l}\text { Basic- includes guest avatar that } \\
\text { cannot be altered and ability to visit } \\
\text { open worlds and build objects in } \\
\text { tutorial } \\
\text { Premium- customizable avatar, } \\
\text { ability to build and own land, abil- } \\
\text { ity to keep list of in-world contacts, } \\
\text { ability to communicate with other } \\
\text { users, extended access to virtual } \\
\text { world sites, and ability to post in } \\
\text { user forums (Active Worlds, } \\
\text { 2010d) }\end{array}$ & $\begin{array}{l}\text { Basic- free } \\
\text { Premium- USD } \\
\text { \$6.95 per } \\
\text { month or } \\
\text { USD } \$ 70 \text { per } \\
\text { year (Active } \\
\text { Worlds, 2010d) }\end{array}$ & $\begin{array}{l}\text { Active Worlds has } \\
\text { no universal cur- } \\
\text { rency - some user- } \\
\text { created worlds have } \\
\text { their own currency } \\
\text { (Active Worlds, } \\
\text { 2010a) }\end{array}$ \\
\hline $\begin{array}{c}\text { Openlife } \\
\text { Grid }\end{array}$ & $\begin{array}{l}\text { Basic- includes customizable ava- } \\
\text { tar, option to purchase land and } \\
\text { build in-world (Openlife Grid, } \\
2010 \text { b) }\end{array}$ & $\begin{array}{l}\text { Basic -free } N o \\
\text { premium mem- } \\
\text { bership (Open- } \\
\text { life Grid, } \\
2010 \mathrm{~b} \text { ) }\end{array}$ & $\begin{array}{l}\text { USD } \$ 75 \text { to OLGC } \\
35,000 \text { (OpenLife } \\
\text { Grid, 2010c) }\end{array}$ \\
\hline
\end{tabular}

Land sales are priced according to the amount of virtual land purchased and the privacy of that land (see Tables 2, 3, and 4). Second Life and Active Worlds both offer special pricing for educational institutions, which does reduce costs but maintenance fees can still total hundreds of US Dollars per month. Moreover, Second Life has indicated that it will phase out its reduced fees for educational institutions, prompting many institutions with Second Life campuses to consider alternatives (Young, 2010). Each world has its system of dividing and selling land, or server space, and its own rules for land use. For the purposes of our study we looked at the cost of a large, private land mass that could accommodate traffic from potential library users. Keep in mind that these prices are only the cost associated with purchasing space within the virtual worlds and do not include the costs associated with creating or buying the content to populate that space.

Table 2: Second Life Pricing List

\begin{tabular}{|c|c|}
\hline \multicolumn{2}{|c|}{ Second Life (Second Life, 2010d) } \\
\hline Private Land Region & USD\$1000+ \\
\hline Education Pricing* & USD\$700+ \\
\hline Monthly Maintenance & USD\$295 \\
\hline Education Pricing* & USD\$147.50 \\
\hline Included & $\begin{array}{c}\text { Terraformed land and sky } \\
\text { (customizable) }\end{array}$ \\
\hline Limitations & $\begin{array}{c}\text { only allow a certain number of } \\
\text { prims (find out about prims in Cre- } \\
\text { ating Content below) }\end{array}$ \\
\hline
\end{tabular}

* This discount will end January 1, 2011 (Chapman, 2010). 
Table 3: Active Worlds Pricing List

\begin{tabular}{|c|c|}
\hline \multicolumn{2}{|c|}{ Active Worlds (Active Worlds, 2010c) } \\
\hline Educational land purchase & USD\$650 \\
\hline Yearly maintenance & USD\$395 \\
\hline Included & $\begin{array}{l}20 \text { simultaneous users and } \\
20 \text { student licenses }\end{array}$ \\
\hline $\begin{array}{c}\text { Expansions for simultaneous } \\
\text { users }\end{array}$ & USD $\$ 150$ for 10 or USD $\$ 500$ for 50 \\
\hline $\begin{array}{l}\text { Yearly simultaneous user } \\
\text { expansion renewal }\end{array}$ & USD $\$ 75$ for 10 or USD $\$ 375$ for 50 \\
\hline Student Licenses expansion & USD $\$ 200$ for 10 or USD $\$ 450$ for 30 \\
\hline $\begin{array}{l}\text { Yearly renewal of student } \\
\text { licenses }\end{array}$ & USD $\$ 200$ for 10 or USD $\$ 450$ for 30 \\
\hline $\begin{array}{c}\text { Fee for student user name } \\
\text { change }\end{array}$ & USD $\$ 30$ \\
\hline
\end{tabular}

Unlike the other worlds reviewed here, Active Worlds limits the number of simultaneous users allowed in the area. Additionally Active Worlds offer licenses for student users. These licenses are assigned to individuals and there is a fee to change the license from one individual to another, which would add up to a significant expense as licenses must be transferred from graduating students to incoming ones.

Table 4: Openlife Grid Pricing List

\begin{tabular}{|c|c|}
\hline \multicolumn{2}{|c|}{ Openlife Grid (Openlife Grid, 2010d) } \\
\hline Private Region monthly fee & USD\$69.95 \\
\hline Included & $\begin{array}{c}\text { approx. 16 virtual acres, 45,000 prim limit } \\
\text { (see Creating content for more informa- } \\
\text { tion about prims), ability to parcel and } \\
\text { rent land, listing in OpenLife Search en- } \\
\text { gine }\end{array}$ \\
\hline Limitations & 45,000 prims \\
\hline
\end{tabular}

Openlife Grid is by far the cheapest and may be a good choice for a smaller school starting out in virtual worlds. As a newer service, however, some of the more advanced features are not yet available, and it is susceptible to glitches and some instability.

\section{Technical Requirements and Support}

Every computer that will be used to access the virtual world needs to have the client software installed and be capable of running the software. All of the virtual worlds require client software be downloaded onto individual computers. Not all virtual worlds will work on all operating systems. 
Additionally we ran all three worlds on a gaming computer build to handle advanced graphics to check for potential lag during multitasking. "Lag" refers to the time it takes for the immediate area of the virtual world to appear and come into focus and for the avatar to respond to a command. The gaming computer we used has the following specs and the perceived lag is listed in Table 5: Dell XPS 630I with Intel Core 2 Quad CPU, 2.67 GHz processor and 3.00 GB RAM and NVIDIA GeForce 9800 GX2 G92, PCI-e X16 1GB Dual DVI and HDMI. The technical requirements and relative performance of the three virtual worlds is shown in Table 5.

Table 5: Virtual World Evaluations

\begin{tabular}{|c|c|c|c|c|}
\hline & Operating System & $\begin{array}{c}\text { Processor and } \\
\text { Memory }\end{array}$ & Graphics & $\begin{array}{l}\text { Lag - on gaming } \\
\text { computer }\end{array}$ \\
\hline $\begin{array}{l}\text { Second Life } \\
\quad \text { (Second } \\
\text { Life, 2010f) }\end{array}$ & $\begin{array}{l}\text { XP, Vista, or Win- } \\
\text { dows } 7 \text { (32-bit on- } \\
\text { ly), Mac OS X } \\
\text { 10.4.11 or better, or } \\
\text { A reasonably mod- } \\
\text { ern 32-bit Linux } \\
\text { environment. If you } \\
\text { are running a 64-bit } \\
\text { Linux distribution } \\
\text { then you will need } \\
\text { its 32-bit compati- } \\
\text { bility environment } \\
\text { installed. }\end{array}$ & $\begin{array}{l}800 \mathrm{MHz} \text { Pen- } \\
\text { tium III or Ath- } \\
\text { lon, or } 1 \mathrm{GHz} \text { G4 } \\
\text { or better and } 512 \\
\text { MB Memory }\end{array}$ & $\begin{array}{l}\text { NVIDIA GeForce } \\
6600 \text { or better, ATI } \\
\text { Radeon } 9500 \text { or bet- } \\
\text { ter, Intel } 945 \text { chip } \\
\text { set or ATI Rade- } \\
\text { on9200 and above, } \\
\text { ATI Radeon X Se- } \\
\text { ries, NVIDIA Ge- } \\
\text { Force } 2, \text { GeForce } 4\end{array}$ & $\begin{array}{l}\text { substantial lag, } \\
\text { especially with } \\
\text { streaming video }\end{array}$ \\
\hline $\begin{array}{l}\text { Active } \\
\text { Worlds } \\
\text { (Active } \\
\text { Worlds, } \\
2010 \mathrm{e} \text { ) }\end{array}$ & $\begin{array}{c}\text { Microsoft Windows } \\
\text { 2000, XP, Vista or } \\
\text { Windows 7, DirectX } \\
7 \text { or later }\end{array}$ & $\begin{array}{l}\text { Pentium } 3 \mathrm{CPU} \\
500 \mathrm{MHz} \text { or } \\
\text { equivalent, } \\
\text { 128MB RAM }\end{array}$ & $\begin{array}{l}\text { D3D video card with } \\
\text { at least } 16 \mathrm{MB} \text { and } \\
\text { the latest drivers }\end{array}$ & some lag \\
\hline $\begin{array}{l}\text { Openlife } \\
\text { Grid (Open- } \\
\text { life Grid, } \\
\text { 2010a) }\end{array}$ & $\begin{array}{c}\text { Micro- } \\
\text { soft Windows 7, } \\
\text { Vista, XP, MAC OS } \\
\text { X, Linux variants } \\
\text { i686 }\end{array}$ & $\begin{array}{c}\text { Intel Pentium } \\
2 \mathrm{Ghz}+\text { or AMD } \\
3000 \text { and above } \\
\text { level processor, } \\
512 \mathrm{Mb} \text { Memory, } \\
\text { 140Mb plus up to } \\
100 \sim 1000 \mathrm{Mb} \\
\text { Cache Disk } \\
\text { Space }\end{array}$ & $\begin{array}{l}\text { 128Mb Video } \\
\text { Memory, Recom- } \\
\text { mended: nVidia or } \\
\text { Ati dedicated graph- } \\
\text { ics chip with } 256 \mathrm{Mb} \\
\text { Memory or higher }\end{array}$ & some lag \\
\hline
\end{tabular}

Speed and processing power of the computer helps reduce lag but there is also less lag with virtual worlds that use more simplified graphics. Other factors that seem to contribute to lag involve the virtual object or image being loaded as well as the virtual world software or servers. We found that multitasking with programs running simultaneously also contributes to lag but can be reduced depending on the computer hardware.

Technical support is another area where the availability and quality vary greatly among the three virtual worlds examined. The most common form of technical assistance in all the worlds is user 
forums. Not all virtual worlds allow posting in forums without a premium membership, but all three allow users to read forum posts with a basic membership.

Second Life has a knowledge base that includes articles and FAQs and allows members to report bugs and other software problems, but does not have an option for requesting individualized support from the developers. Second Life does provide user forums for requesting support from other, knowledgeable community members. Users must log in to access the forums, which they can do with a basic membership. Active Worlds provides a searchable FAQ, troubleshooting guides, and a public wiki. Although there are user forums that can be read for free, only paid citizens are able to post questions on the forums. There is an email form to request individualized technical support; however, that is also only available to paid citizens with a premium membership. Openlife Grid has a blog with software updates and information, and user wikis and forums for finding information and asking questions of the community, but no official technical support.

\section{Using the Virtual World}

None of the virtual worlds require a credit card for a basic account but all have premium options requiring payment. For basic accounts, most virtual worlds require that the user fill in a form including the user's real name and a real email address. Second Life and Active Worlds both have tutorials available to teach new users how to function in-world. Overall the learning curve for virtual worlds varies. Active Worlds is less demanding than Second Life when it comes to effectively moving about the world and using the tools provided. Openlife Grid is sufficiently like Second Life that anyone familiar with Second Life would easily be able to use Openlife Grid. However, as of this writing, many of the features, such as maps and search options for navigation, and some of the help forums in Openlife Grid were not yet available. Second Life is the most complex and takes a real commitment of time to learn. Patrons will need training in learning to use virtual worlds, in addition to continuing support.

\section{Navigating the World}

All of the virtual worlds allow movement of the avatars by using the arrow keys on the keyboard. Navigation in virtual worlds can primarily be accomplished in two ways: having your avatar walk or fly from one place to another or by teleporting directly to a location. A teleporting avatar disappears from one location and reappears in another. Not all of the virtual worlds use the term 'teleporting' but all have the capability and the word is used regularly in discussions of all the virtual worlds examined here. Second Life and Active Worlds each have a search option to find places by name or theme. Avatars may teleport directly to areas found within search results, provided the areas are not restricted. The search option in Second Life is not particularly effective when looking for themed areas. Metadata is provided by area owners and is not always sufficient to conduct a productive search. Searching for places is most effective when the exact title of a destination is known. In each virtual world, it is also possible to teleport from one place to another by selecting an area on the world maps. Walking and flying in all of the worlds is only effective when areas are adjacent to each other. In Openlife Grid many areas are sufficiently far apart to make walking from place to place ineffective.

\section{Interacting with the World}

All the worlds have menus that can be accessed in a variety of ways and that contain commands to initiate other actions including having the avatar perform gestures such as sitting down. One way to access a menu is left-clicking on an object; this opens a window with options about what the avatar can do with the object. This action is possible in all of the worlds, although options available in the menu vary according to the object. Learning to use the controls is not hard but does take some time for adjustment, especially in Second Life and Openlife Grid. Second Life 
has menus that open when the avatar touches an object but also has redundant controls in the menus located at the top and bottom of the screen. It usually takes several hours of committed time to learn each world's range of controls.

In all the virtual worlds, avatars are provided with an "inventory." An inventory, which may have different names in different worlds, is a file or files attached to an individual avatar containing objects, instructions, information, or various types of virtual world building blocks for constructing content. The inventory may also contain bookmarks for various sites in-world, usually allowing the user to teleport instantly to the landmarked site. In Second Life it is easy to acquire a large inventory without spending in-world money. Most new places an avatar visits will automatically insert a landmark in the inventory or offer information cards for future reference. Users should be prepared to create folders and organize their own inventory in Second Life. As users acquire objects they may also find unwanted objects that can clutter their inventory and should be deleted.

\section{Interacting with Other People}

All of the virtual worlds have a text-based chat feature which allows users to chat with their friends and with other avatars. Some of the virtual worlds, including Second Life, also have an audio option. This feature, however, requires additional hardware, such as a microphone. All of the virtual worlds explored for this paper allow users to create groups, maintain friend lists, and report harassing behavior. The quality of the chat function can vary; Second Life's chat, in particular, is confusing to use when multiple conversations occur. It is not always obvious when an individual attempts to communicate, and switching among conversations is cumbersome. Active Worlds, unlike the other virtual world programs, does not allow any chatting unless you are a paid premium member. This makes it nearly impossible for those with free memberships to collaborate in-world.

There are a number of universities and libraries with a presence in Second Life. Most of them opt to create an environment that mirrors a university campus with green space, classroom buildings, and other identifiable landmarks. Some universities host virtual meetings in these buildings; many of the university campuses host both actual classes for students and collaborative meetings among faculty members and staff. The problem with this model is that it is not that different from what is already available in the real world. There are few real benefits to creating a virtual mirror-image of a university campus. A website tour of campus with pictures, for example, would serve the same purpose and use a platform with which users are already comfortable.

Virtual meetings in immersive environments likewise provide few benefits not obtained from simple chat room-based meetings. Although the ability to view a person-shaped avatar of attendants may add a visual element lacking in chat software, the high learning curve for navigating immersive environments like Second Life and the cumbersome nature of the in-world chat software offsets the visual benefit. In the in-world meetings and presentations the authors attended, significant time was spent by the presenter helping attendees find the meeting place, manage the chat software, and control their avatar. This takes time away from the actual meeting or presentation, and leads to frustration.

\section{Creating Content}

Perhaps the most important aspect of maintaining a presence in any virtual world is that of creating content. From virtual buildings, landscaping, and furniture to readable content, audio and video files, and website links, a virtual world site is only as good as the content it provides. And, like the other aspects of working with virtual worlds, each virtual world is different in the methods, abilities, and limitations it places on user-created content. 
Second Life and Openlife Grid have the same tools for building in-world. The tools are difficult to use and can be quite frustrating since they require users to build objects in layers. The first layer is called a prim, referring to a simple shape such as a cube or a sphere. Building in Second Life requires creating the necessary prims and then assembling them. For instance, a chair might require the creation of six rectangular prims shaped into a chair, and bound together with the available building tools. The chair can be texturized by using images from an avatar's inventory. By applying texture and other characteristics like coloring or shadowing, a user may create a realistic looking kitchen chair. Special action scripts can also be applied to objects; a chair, for example, may include a script that will allow avatars to sit on it. At first, the tools in Openlife Grid seemed to function more smoothly than those of Second Life but significant glitches prevented us from repositioning objects we had created. One object even sank into the ground for no apparent reason and all attempts to reach it proved fruitless.

Ready-made objects may also be purchased. This reduces the amount of time spent building; however, these objects cost real money and are not free of glitches. Glitches may occur based on an interaction with an object or because of the environment where a user's avatar is located. One of the authors, for example, found herself sitting in her chair rather than on it for the entirety of a virtual panel discussion. Glitches may also include the loss of an object or unappealing changes occurring in an avatar's appearance and dress. Ready-made objects in Second Life may also come booby-trapped with scripts written to damage the avatar or environment. Users who choose to acquire objects in-world should be careful about purchases, especially in Second Life. More about these risks can be found in the Overview of Risks Involved section below. Finally, readymade objects may exceed the number of prims allowed within a particular piece of land. Although prim limits can usually be raised, for a price, this is an important consideration.

Once a site in a virtual world exists, the addition of content such as images, video, or links represents another issue. In Second Life all images, textures, videos, and links brought in from outside are charged a fee per item of L $\$ 10$. Libraries that choose to build in-world should be prepared to seek out the specifics of policies and rules such as this one, as none of these worlds keep all information in one place. As noted earlier, site content can be subject to substantial lag, complicated by the fact that the bandwidth available to upload items (images, video, etc.) in-world is very small.

All areas in Second Life can be rated with a General, Moderate, or Adult rating. The General rating applies to areas where content is appropriate for anyone under the age of 13. Adult areas contain content that includes sex, violence, and drug use. Moderate areas constitute anything in between General and Adult. Content added to the area must be appropriate to the area rating. Linden Labs retains the right to re-designate area ratings, but will only do so if they receive valid complaints about inappropriate content. Linden Labs does not acknowledge any obligation to change area ratings or to remove content (Second Life, 2010c).

Of all the virtual worlds discussed here only Openlife Grid allows content creators to own their own content. Second Life only acknowledges content creators copyrights. There is more discussion on appropriate content and virtual world copyrights in the Overview of Risks Involved section below.

In Active Worlds, the only way to build is to "clone" and adapt an already-existing object. If you are an Active Worlds' tourist (non-paying user) you are restricted in what you can do in terms of creating content. If you do not own the land you are building on, you are limited to copying approved objects and changing their positioning. Only landowners can actually create something new or really different. 


\section{Overview of Risks Involved}

Virtual worlds, especially Second Life, are primarily commercial enterprises, not educational entities. They are interactive environments with users from all over the world who come in-world for various reasons. Before adopting any of the virtual worlds it is recommended that interested parties carefully read the licensing and terms of service (TOS).

These agreements all limit the liability the virtual world provider accepts in terms of content and functionality of the virtual worlds. This means that if the system crashes and content is lost or an event is canceled, the virtual world service provider will not protect or cover any potential loss. Additionally, user created content is never owned by the user in any of the virtual worlds except in the case of Openlife Grid. Although Second Life acknowledges copyrights for intellectual property created, it reserves the right to remove and/or delete any user created content at any point (Second Life, 2010g). All three virtual worlds reserve the right to remove content or terminate service at their sole discretion and are not legally obligated to offer a reason for doing so. Any of the virtual world service providers can remove a site or created content at any time without notice, explanation, or refund of money spent to build these items.

Of the two worlds that do not allow you to own content only Second Life allows users to retain copyright. Active Worlds' TOS does not mention copyrights for items created in-world but items in Active Worlds are modified from existing objects so intellectual property may be an issue for anyone building here (Active Worlds, 2010b). Second Life's policy on copyright requires copyright owners to notify Linden Labs in writing that a copyright infringement has occurred. Once the notice is received Linden Labs will remove the content in accordance with the Digital Millennium Copyright Act. The person whose content was taken down may file a counter-notification if they do not believe they have infringed copyright and Linden Labs will put the content back up unless ordered to remove it by court order. Virtual worlds are currently treated as internet service providers (ISPs) under copyright law.

It is possible to protect created objects from being modified or destroyed by other users but the added protection requires more building time and an understanding of the building tools and scripting languages. Second Life is rife with reports of griefing and other offenses. Griefing refers to the practice of users who specifically antagonize other users. This includes showering an area with unwanted items, such as pornographic images, or staging an attack that will damage objects or avatars in-world.

The virtual environments have their own cultures and economies. The Second Life economy includes pornography and a thriving virtual sex trade with users coming in-world to perform virtual sex acts. New users are prime targets to be lured into virtual nightclubs, brothels, and other areas with Adult designations. Other users engage in violent behavior, which includes the use of virtual weapons, such as guns, which can damage another user's avatar. An unwary new user may be given a 'gift' that is scripted to allow another user to take control of their avatar. Users can guard against this malicious behavior but it requires initiative to explore objects or add protective objects or scripts.

Safeguards are not universal and sometimes need to be added per environment and sometimes per object. This increases the amount of training and skill that users need to learn for safe navigation through virtual worlds. There exist fewer reports of unsavory user behavior in Active Worlds and OpenLife Grid but, as stated at the beginning of the article, Second Life represents the majority of the available literature, overall.

All virtual worlds have options to report destructive and abusive behavior but there is little data on how quickly, if ever, problems are resolved (Bugeja, 2007). None of the three virtual worlds investigated for this paper accept responsibility or liability for content. Although they all reserve 
the right to remove content, they accept no responsibility for monitoring objectionable content. Linden Lab's Chief Technology Officer asserted in 2007 that "it is not possible for us to police the whole place. . Even when the police find out about some crime it's because some other citizens call them" (Yuen-C, 2007).

Another risk factor is the virtual world market. In-world currency has real world value, but the inworld market is less regulated. No governing bodies provide oversight of the in-world economy besides the virtual world service provider. Virtual worlds' primary source of revenue is selling land, in which users invest to create real-world revenue. Initially, Second Life developed a large and fairly robust economy that attracted new virtual world entrepreneurs and even established real world businesses and corporations. However, by 2007, large businesses and corporations left Second Life because of low consumer traffic (Neate, 2009).

Other problems with financial risk in virtual worlds are evident through the repercussions of Second Life's ban on gambling in the summer of 2007. The ban came about because Second Life was unable to comply with "conflicting gambling regulations around the world" (Sidel, 2008). This ban closed several in-world businesses and created a downturn in the virtual economy. The economic problem was exacerbated by in-world banks that were promising enormous returns on investments without being backed by real world currency. The panic caused by the gambling ban resulted in an economic crash in early 2008 in which Second Life depositors may have lost as much a USD \$750,000 (Sidel, 2008). As a result, in-world banks in Second Life are now required to have a real world charter.

The market has an impact on in-world educational sites for several reasons. The market impacts the amount and type of traffic that can be expected. Also, we cannot expect our users to go inworld for our site and never to become involved in any other aspect of the virtual world. Users who become involved in virtual worlds because of the encouragement of a library may choose to engage in business or other activities with negative outcomes. While libraries may have no actual liability for the behavior of individual users, they may be penalized for user behavior. For example, Linden Labs shut down and removed the site for Woodbury University because of reports of inappropriate behavior of users associated with the site (Foster, 2007, p. 22). This is simply one example of how virtual worlds pose real dangers that are may not be evident or controlled.

\section{Findings}

After exploring the basic functions and suitability of the three different virtual worlds, the authors applied their findings to the library functions described at the outset of this paper. A true analysis of the value of virtual worlds for library services should take into account the current virtual populations. Not all virtual worlds provide demographics but the average real-life denizens of virtual worlds are in their thirties (Gillis, 2009). However, the university students who will be visiting an in-world site will be in their early twenties. The new CEO of Second Life, Mark Kingdon, announced the intention of Second Life to pursue three markets including consumers, education, and enterprise. Out of these three, Kingdon noted that consumers are the only market already present in the virtual world (Wagner, 2008).

\section{Reference}

Reference Services are possible in virtual environments because they are equipped for communication between users. However, a successful reference service requires trained staff, defined inworld staff hours, and an understanding that the majority of users will be new to virtual worlds and may need technical help rather than library information. The success of in-world staffed services such as reference are influenced by pre-existing traffic to the virtual world site coupled with the ability to draw new users in-world. An impromptu survey of 170 undergraduate students in 
information literacy classes yielded only 2 responders who had ever heard of Second Life and none who had ever been in-world. The authors' own experiences in-world featured many visits to remarkable educational sites that were completely empty of other users. Finally, bandwidth and licensing restrictions limit the quality of reference interviews because the librarian may be unable to show the user the library OPAC or databases in real time. For these reasons we determined that staffed reference services are not advantageous in virtual world settings.

\section{Collection Access}

It is possible to link a library catalog in-world; however, the links may cost money and require substantial maintenance. Additionally, libraries must forget about access to subscription databases because of licensing restrictions. Some libraries have created actual library buildings within Second Life in order to serve patrons in-world. While some of these buildings are visually impressive, the content they provide rarely goes beyond objects that link to external web pages, such as a computer terminal one can sit at but which, when clicked, simply opens the library's homepage in another browser window. It does not seem practical to make the effort when most patrons will look for the website before looking for the virtual world site. Ultimately, these types of recreations do not serve the purpose of interesting a library's traditional patrons in virtual worlds.

\section{Exhibits and Outreach}

Immersive environments like Second Life do excel in the creation of topical modules analogous to themed exhibits in a library. These exhibits, called "sims" in Second Life, are capable of presenting a much richer experience because of their immersive nature and ability to incorporate a wider variety of material than is usually practical in a physical library building, making virtual worlds a good place to create exhibits. These educational sims are most effective for topics such as history and literature, where they are able to recreate a historical time period or the setting of a novel, allowing the visitor to experience the world invoked.

Second Life currently provides several examples of this kind of educational module. The Land of Lincoln focuses on the life of Abraham Lincoln and includes a small-town street with a general store displaying common products at historically-accurate prices, a newspaper office in which one can view PDF images of "The Liberator," an abolitionist newspaper, and a library in which one can read Project Gutenberg texts of books popular in Lincoln's time. There is also a Civil War era military camp site, in which one can listen to the song 'Taps' while viewing Civil War brigade flags, and a model of the White House as it looked when Lincoln lived there. A visitor can wander through the bedrooms and see the period furnishings, explore the Hall of Presidents and view portraits of previous U.S. Presidents with brief biographies, or even check out the kitchen area or the coal storage and furnaces in the basement. Free period clothes offered at the entrance allows the visitor to 'dress up' their avatar to better fit in with the time period. The 3-D nature of the immersive environment provides context for the information provided and helps to provoke an emotional response, further aiding in the absorption of the material presented.

The time and programming skill necessary to build one of these sims is immense, as is the bandwidth needed to load them. Only high-end computers are able to load the sims without considerable lag - lesser or older machines run the program so slowly as to make the experience all but worthless. Moreover, the sims work best when they are focused on a single integrated topic, which precludes their use in traditional bibliographic instruction. While a topical sim such as Land of Lincoln might be appropriate to showcase a special collection or library exhibit, they are not suited to day-to-day library activities or general collections. There has been some success with virtual exhibits that are akin to poster sessions, with text and images giving information on a topic appearing on a wall or large screen. Unfortunately, these types of exhibits are particularly susceptible to lag in Second Life, and patrons often get tired of waiting for the information to 
load. Nevertheless Second Life and Openlife Grid may still be the best place to build sims for outreach and exhibit purposes since Active Worlds has strict limits on the number of users a world can have and where a non-paying visitor may go, making it ineffective for outreach.

\section{Instruction}

Lastly, we considered the use of virtual worlds for information literacy instruction. Like the creation of sims for library exhibits, it is possible to create instructional modules that lead a user through a particular lesson or topic. However, the features of the virtual world determine what the modules will be like. In Second Life information including quizzes can be created in Notecards which do not allow for creative formatting much less media rich content. The quality of streaming video and audio are subject not only to the virtual environment but to the individual computer being used. Therefore, there is no way to ensure that all users will be having the same experience in the tutorial.

Aside from tutorials, there is also the option of real-time instruction in-world. Several university presences in Second Life already include virtual "classrooms." Like with many other re-creations of real life scenarios in-world, this model of instruction comes with significant challenges. Holding real-time instruction sessions in-world requires all participants to have downloaded the virtual world software, registered, and have mastered the basics of in-world interaction. Users must then navigate to the virtual location in which the instruction is taking place and either have the software and hardware necessary for VOIP (voice-over internet protocol - a system that allows users with microphones and speakers/headsets to speak over the internet) or deal with the overlapping conversations that are a trademark of most chat software in-world. Technical difficulties and the differing technical abilities of individual student computers frequently mean that significant portions of time intended for instruction are instead consumed with assisting the student in managing the virtual world experience. Additionally, instructors should have all course content loaded inworld, as opposed to linking to outside resources, because there is no way for instructors to monitor what the students are seeing or doing when outside of the world. This complication makes answering real-time questions and demonstrating library catalogs and databases difficult if not impossible.

Because of these challenges we do not recommend virtual worlds in their current incarnation be used for real-time instruction purposes. Nevertheless, libraries wishing to engage in real time instruction should prepare their in-world space and check that all participants have the necessary hardware, software, and know how to function in the virtual environment well before the instruction is to take place. And, although we would make the same virtual world recommendations for asynchronous sim-like instruction modules as we would for sims, we found no real advantages to any of the virtual worlds for instruction.

\section{Discussion and Conclusions}

One of the biggest benefits of this project was identifying the challenges with using virtual worlds for library services. Aside from considering the details associated with starting and maintaining a presence in a virtual world, the safety and suitability of virtual environments should be a significant consideration. Bugeja (2007) points out that "the true motive of technological interfaces and applications is often money" and warns that creating a presence in a virtual world can carry with it unanticipated risks and responsibilities. Similarly, Valerie Hill and Hyuk-Jin Lee write that "important issues need to be investigated...legal issues regarding copyright law, privacy and security need to be scrutinized" (Hill \& Lee, 2009, p. 354). Whether the issues are money, risk, or functionality, there is much to take into account when considering a presence in a virtual world. Although the virtual environment's most vocal critics, such as Michael Stoner, assert that "the effort and money spent to understand the virtual world may not be worth it," the current enthusi- 
asm concerning virtual worlds within the library community makes it nearly impossible for a library institution to avoid considering the virtual environment as a potential tool (Foster, 2007, p. 22).

Furthermore, extremely successful and appropriate examples of virtual worlds in higher education and libraries currently exist. Lynette Ralph and Beth Stahr (2010) offer Southeastern Louisiana University's Sims Library as an example of a library using Second Life to deliver services and reach students in a way that no other technology could. As a "commuter campus...considered the second-largest provider of distance education in Louisiana," Southeastern Louisiana University and its Sims Library uses Second Life to provide additional services for distance learners (Ralph $\&$ Stahr, 2010, p. 910). Similarly, Sara de Freitas and her colleagues mention the use of Second Life for reaching "under-served learners" in a way that no other technology would be able to (de Freitas, Rebolledo-Mendez, Liarokapis, Magoulas, \& Poulovassilis, 2010, p. 83). In what represents perhaps the best example of a truly appropriate use of the virtual world environment for education, Diane Skiba pulls together a list of health care education initiatives that offer immersive opportunities to train emergency responders, nurses, and workers in disease control and terrorism $(2007$, p. 157). Essentially, Second Life and other virtual worlds offer the potential of real value, even though the research presented in this study discusses the barriers, risks, and downsides of the incarnation of virtual worlds today. For libraries, this paper simply offers a range of ideas for consideration during the discussion of using a virtual world for instruction, outreach, or other services.

Of the virtual worlds examined here Second Life represents the most well-established and well known virtual world, already containing many sites that would complement and enhance library sites. Openlife Grid may be too new to be a serious contender at this point. As a new virtual world that has chosen to retain Second Life's operability, it is up against serious competition from new virtual worlds that are easier for users without virtual world scripting and building skills. In the current climate it is too early to say whether Openlife Grid will ever be a viable option. Active Worlds may be a good consideration for a smaller library that wishes to create a private area with limited access.

But a better choice may be to wait. Virtual worlds are a remarkable new technology. They present avenues for new ways of examining social interaction and of exploring what educational institutions can do with newer technologies. However, in their current incarnation they do not seem to meet most of the needs of academic libraries. In order to truly meet the needs of academic libraries the following changes to what is currently available would need to be made:

1) A web-based interface that does not require better than average hardware

2) A start-up time of less than 1 hour including registration, download, and beginner tutorials.

3) Easy and clear navigation with a searchable database of places and events that is easy to use.

4) Standard landmarks (in-world bookmarks) for each user associated with the library site including the library site and in-world user tutorials.

5) Sufficient bandwidth to allow media rich content and even partial access to the library collection.

6) Ideally, an established population of college age users

Perhaps the best option for academic libraries in virtual worlds is not to find out how we can fit into what is currently available but to demand an interface that meets our needs. In their research, Diane Sonnenwald and her colleagues found evidence indicating that "characteristics of and challenges facing library and information science research and practice may also inspire new advances" in virtual worlds and other virtual environments" (Sonnenwald, et al., 2009, p. 201). 
This research suggests that library practitioners and researchers, by researching their specific needs relating to virtual worlds, can and should request that relevant changes be made in virtual worlds used for education. One option for enacting this would be the development of a consortium of academic libraries to take our requirements to a virtual world developer. In light of the current landscape with established virtual worlds on the tail end of the technology hype cycle and new developers looking to build better things from the lessons already learned this may be the ideal time for librarians and other educators to become involved at the beginning of the process instead of the end. We know we are a market that virtual worlds are interested in, so let's get what we want out of the deal.

\section{References}

Abram, S. (2008). Foreword. In L. Bell \& R. B. Trueman (Eds.), Virtual worlds, real libraries: Librarians and educators in Second Life and other multi-user environments (pp. xi). Medford, NJ: Information Today, Inc.

Active Worlds. (2010a). Active Wiki. Retrieved November, 12, 2010, from http://wiki.activeworlds.com/index.php?title=Main_Page

Active Worlds. (2010b). Active Worlds content guidlines. Retrieved July 15, 2010, from http://www.activeworlds.com/community/terms.asp

Active Worlds. (2010c). Active Worlds educational universe pricing information. Retrieved November 12, 2010, from http://www.activeworlds.com/edu/awedu_pricing.asp

Active Worlds. (2010d). Become a virtual world citizen. Retrieved November 12, 2010, from http://www.activeworlds.com/products/citizenships.asp

Active Worlds. (2010e). Downloads. Retrieved November 12, 2010, from http://www.activeworlds.com/products/download.asp

Alliance Library System. (2010). What does the Alliance Library System (ALS) actually do? Retrieved July 14 2010, from http://www.alliancelibrarysystem.com/aboutUs1/whatWeDo.cfm

Bell, D. (2009). Learning from Second Life. British Journal of Educational Technology, 40(3), 515-525.

Bell, L., Peters, T., \& Pope, K. (2007). Get a (Second) Life! Computers in Libraries, 27(1), 10-15.

Bell, L., Pope, K., \& Peters, T. (2007). Digital libraries on the MUVE: A Virtual Adventure. Bulletin of the American Society for Information Science \& Technology, 33(4), 29-29.

Bell, L., Pope, K., \& Peters, T. (2008). The university library in a virtual universe. Searcher, 16(5), 26-61.

Bell, L., \& Trueman, R. B. (2008). Introduction. In L. Bell \& R. B. Trueman (Eds.), Virtual worlds, real libraries: Librarians and educators in Second Life and other multi-user virtual environments (pp. xv). Medford, N.J.: Information Today.

Boxen, J. L. (2008). Library 2.0: A review of the literature. Reference Librarian, 49(1), 21-34.

Brookey, R. A., \& Cannon, K. L. (2009). Sex lives in Second Life. Critical Studies in Media Communication, 26(2), 145-164.

Bugeja, M. J. (2007). Second thoughts about second life. Chronicle of Higher Education, 54(3), C2-C4.

Cartelli, A., Stansfield, M., Connolly, T., Athanassios, J., Magalhaes, H., \& Maillet, K. (2008). Towards the development of a new model for best practice and knowledge construction in virtual campuses. Journal of Information Technology Education 7, 121-134. Retrieved from http://www.jite.org/documents/Vol7/JITEv7p121-134Cartelli397.pdf

Chapman, P. (2010). Second Life to drop educational discount. Wired Campus. Retrieved October 6, 2010, from http://chronicle.com/blogs/wiredcampus/second-life-to-drop-educational-discount/27458 
de Freitas, S., Rebolledo-Mendez, G., Liarokapis, F., Magoulas, G., \& Poulovassilis, A. (2009). Developing an evaluation methodology for immersive learning experiences in a virtual world. Games and Virtual Worlds for Serious Applications, 2009, Coventry, UK, 43-50.

de Freitas, S., Rebolledo-Mendez, G., Liarokapis, F., Magoulas, G., \& Poulovassilis, A. (2010). Learning as immersive experiences: Using the four-dimensional framework for designing and evaluating immersive learning experiences in a virtual world. British Journal of Educational Technology, 41(1), 69-85.

De Lucia, A., Francese, R., Passero, I., \& Tortora, G. (2009). Development and evaluation of a virtual campus on Second Life: The case of SecondDMI. Computers \& Education, 52(1), 220-233.

Dell, K. (2007). Second Life's real-world problems. Time, 170(8), 49-50.

Demetrious, K. (2008). Secrecy and illusion: Second Life and the construction of unreality. Australian Journal of Communication, 35(1), 1-13.

deWinter, J., \& Vie, S. (2008). Press enter to "say": Using Second Life to teach critical media literacy. Computers \& Composition, 25(3), 313-322.

Edirisingha, P., Nie, M., Pluciennik, M., \& Young, R. (2009). Socialisation for learning at a distance in a 3D multi-user virtual environment. British Journal of Educational Technology, 40(3), 458-479.

EDUCAUSE. (2006). 7 things you should know about virtual worlds. EDUCAUSE Learning Initiative. Retrieved November 11, 2010, from http://www.educause.edu/ELI/7ThingsYouShouldKnowAboutVirtu/156818

EDUCAUSE. (2007). 2007 Horizon Report. Austin, TX.

Erdman, J. (2007). Reference in a 3-D virtual world: Preliminary observations on library outreach in "Second Life." Reference Librarian, 47(2), 29-39.

Floyd, J., Frank, I., McOok, K. D. L. P., \& Smith, A. (2007). Second Life for librarians. Florida Libraries, 50(1), 4-7.

Ford, C. E., Gerardin, J., Yamamoto, M., \& Gordon, K. (2008). Fresh perspectives on reference work in Second Life. Reference \& User Services Quarterly, 47(4), 324-330.

Foss, J. (2009). Lessons from learning in virtual environments. British Journal of Educational Technology, $40(3), 556-560$.

Foster, A. L. (2007). The death of a virtual campus. Chronicle of Higher Education, 53(45), A22-25.

Galarneau, L. L. (2009). Spontaneous communities of learning: Cooperative learning ecosystems surrounding virtual worlds. Doctoral Dissertation, University of Waikato. Retrieved from http://lgalarneau.webs.com/dissertation.htm

Gartner, I. (2007). Gartner says 80 percent of active internet users will have a "Second Life" in the virtual world by the end of 2011. Retrieved November 8, 2010, from http://www.gartner.com/it/page.jsp?id=503861

Gillis, R. (2009, 5 January). You only live twice. The Irish Times, p. 54

Gilson, D. (2007). Even better than the real thing. Mother Jones. Retrieved November 8, 2010, from http://motherjones.com/politics/2007/05/even-better-real-thing

Greenhill, K. (2008). Do we remove all the walls? Second Life librarianship. Australian Library Journal, 57(4), 377-393.

Grover, M. (2008). Library, education, and museum applications of virtual worlds for child, tween, and teen projects. In L. Bell \& R. B. Trueman (Eds.), Virtual worlds, real libraries: Librarians and educators in Second Life and other multi-user environments (pp. 19-32). Medford, NJ: Information Today, Inc.

Hill, V., \& Lee, H.-J. (2009). Libraries and immersive learning environments unite in Second Life. Library Hi Tech, 27(3), 338-356. 
Hurst-Wahl, J. (2007). Librarians and Second Life. Information Outlook, 11(6), 45-53.

Jarmon, L., Traphagan, T., Mayrath, M., \& Trivedi, A. (2009). Virtual world teaching, experiential learning, and assessment: An interdisciplinary communication course in Second Life. Computers \& Education, 53(1), 169-182.

Jennings, N., \& Collins, C. (2007). Virtual or irtually U: Educational institutions in Second Life. International Journal of Social Sciences, 2(3), 180-186.

Kattelman, B. (2008). It's time for a Second Life. College \& Research Libraries News, 69(10), 614-617.

Kelton, A. J. (2008). Virtual worlds?. Educause Review, 43(5), 15-22.

Lee, S., Fox, A., Marchionini, G., Velacso, J., Antunes, G., and Borbinha, J. (2009). Virtual dl poster sessions in Second Life [Abstract]. Proceedings of the 9th ACM/IEEE-CS Joint Conference on Digital Libraries, Austin, TX, USA, 473.

Luo, L., \& Kemp, J. (2008). Second Life: Exploring the immersive instructional venue for library and information science education. Journal of Education for Library \& Information Science, 49(3), 147166.

Mathews, B. (2007). Moving beyond the reference desk: Being where users need us. Reference Librarian, 48(2), 9-13.

Messinger, P. R., Stroulia, E., Lyons, K., Bone, M., Niu, R. H., Smirnov, K., \& Perelgut, S. (2009). Virtual worlds - past, present, and future: New directions. Decision Support System,s 47(9), 204-228.

Middleton, C. (2009, 27 January). Business \& technology. Computer Weekly.

Neate, R. (2009, 31 March). Second Life's span is virtually over as forms decide to get real. The Daily Telegraph, p. 5.

Openlife Grid. (2010a). Downloads. Retrieved November 12, 2010, from http://openlifegrid.com/Downloads/tabid/67/Default.aspx

Openlife Grid. (2010b). Getting started in 3 easy steps. Retrieved November 12, 2010, from http://openlifegrid.com/Main/GettingStarted/tabid/381/Default.aspx

Openlife Grid. (2010c). Openlife grid. Retrieved November, 12, 2010, from http://openlifegrid.com/Main/tabid/36/Default.aspx

Openlife Grid. (2010d). Virtual land. Retrieved November, 12, 2010, from http://openlifegrid.com/VirtualLand/tabid/63/Default.aspx

Pierce, J. B. (2009). It's not all fun and games. American Libraries, 40(4), 61-61.

Porter, C. E. (2004). A typology of virtual world communities: A multi-disciplinary foundation for future research. Journal of Computer-Mediated Communication, 10(1). Retrieved November 8, 2010, from http://jcmc.indiana.edu/vol10/issue1/porter.html

Purpur, G., \& Ochoa, L. (2008). New frontiers for distance learning library services: A virtual world library at Appalachian State University. In L. Bell \& R. B. Trueman (Eds.), Virtual worlds, real libraries: Librarians and educators in Second Life and other multi-user environments (pp. 183-192). Medford, NJ: Information Today, Inc.

Ralph, L., \& Stahr, B. (2010). When off-campus means virtual campus: The academic library in Second Life. Journal of Library Administration, 50(7), 909-922.

Salmon, G., \& Hawkridge, D. (2009). Editorial: Out of this world. British Journal of Educational Technology, pp. 401-413.

Sanchez, J. (2009). Barriers to student learning in Second Life. Library Technology Reports, 45(2), 29-34.

Sbrunozzi. (2008). His first two months at Linden Lab. Retrieved November 8, 2010, from http://www.secondlifepros.com/2008/07/his-first-two-months-at-linden-lab/ 
Second Life. (2010a). Beginner landowners FAQ. Retrieved November 12, 2010, from http://wiki.secondlife.com/wiki/Frequently_Asked_Questions_from_Beginning_Landowners

Second Life. (2010b). LindeX market data. Retrieved November 12, 2010, from http://secondlife.com/statistics/economy-market.php

Second Life. (2010c). Maturity ratings: An overview. Retrieved July 14, 2010, from http://wiki.secondlife.com/wiki/Linden_Lab_Official:Maturity_ratings:_an_overview

Second Life. (2010d). Private region pricing. Retrieved November 12, 2010, from http://secondlife.com/land/privatepricing.php

Second Life. (2010e). Second Life statistics. Retrieved July 14, 2010, from http://secondlife.com/xmlhttp/secondlife.php

Second Life. (2010f). System requirements. Retrieved November, 2010, from http://secondlife.com/support/system-requirements/

Second Life. (2010g). Terms of service. Retrieved July 14, 2010, from http://secondlife.com/corporate/tos.php

Second Life. (2010h). Why teach in Second Life? Retrieved July 14, 2010, from http://education.secondlife.com/whysl/faqs/\#faq-cost-1

Sidel, R. (2008, January 23). Cheer up, Ben: Your economy isn't as bad as this one - In the makebelieve world of Second Life, banks are really collapsing. The Wall Street Journal, p. A1.

Skiba, D. J. (2007). Nursing education 2.0: Second Life. Nursing Education Perspectives, 28(3), 156-157.

Sonnenwald, D. H., Lassi, M., Olson, N., Ponti, M., \& Axelsson, A.-S. (2009). Exploring new ways of working using virtual research environments in library and information science. Library Hi Tech, 27(2), 191-204.

Tennesen, M. (2009). Avatar acts. Scientific American, 301(1), 27-28.

Thompson, S. H. (2009). On being a virtual world librarian: "Hello, can I help?" - Managing virtual volunteers. Reference Librarian, 50(4), 422-427.

Twining, P. (2009). Exploring the educational potential of virtual worlds-Some reflections from the SPP. British Journal of Educational Technology, 40(3), 496-514.

Vogel, D., Guo, M., Zhou, P., Tian, S., \& Zhang, J. (2008). In search of SecondLife nirvana. Issues in Informing Science and Information Technology, 5, 11-28. Retrieved from http://proceedings.informingscience.org/InSITE2008/IISITv5p011-028Vogel498.pdf

Wagner, M. (2008). Second Life tries for a second act. Information Week. Retrieved November 8, 2010, from

http://www.informationweek.com/news/personal tech/virtualworlds/showArticle.jhtml;jsessionid=ZNI UETFI3TYGNQE1GHOSKHWATMY32JVN?articleID=210602194

Warburton, S. (2009). Second Life in higher education: Assessing the potential for and the barriers to deploying virtual worlds in learning and teaching. British Journal of Educational Technology, 40(3), 414-426.

Wheeler, M. (2009). Developing the Media Zoo in Second Life. British Journal of Educational Technology, 40(3), 427-443.

Young, J. (2010). Academics consider mass migration from Second Life. Wired Campus. Retrieved November 8, 2010, from http://chronicle.com/blogs/wiredcampus/academics-discuss-mass-migrationfrom-second-life/27672

Yuen-C, T. (2007, July 10). Another world in the background. The Straits Times (Singapore). 


\section{Biographies}

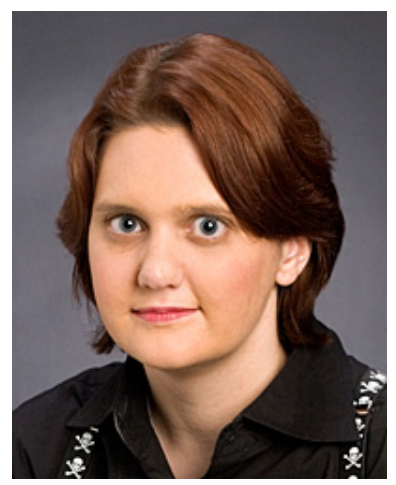

Jenna Ryan is a Reference and Instruction Librarian and the Virtual Reference Coordinator at Louisiana State University in Baton Rouge. She earned her MLIS from the University of South Carolina in Columbia. Her research interests include virtual reference, social networking in the classroom, emerging technologies, and bibliographic instruction.

Marjorie Porter is a librarian at the National Agricultural Library in Beltsville, MD where she is working on the development of a public information clearinghouse designed to assist prospective and beginning farmers. Previously, she worked in reference and instruction services at Louisiana State University. She received her MA in Information Resources and Library Science from the University of Arizona. Her research interests include knowledge management, information seeking behavior, and instructional design. She is the co-editor of Best Practices in Corporate Libraries which will be published in 2011

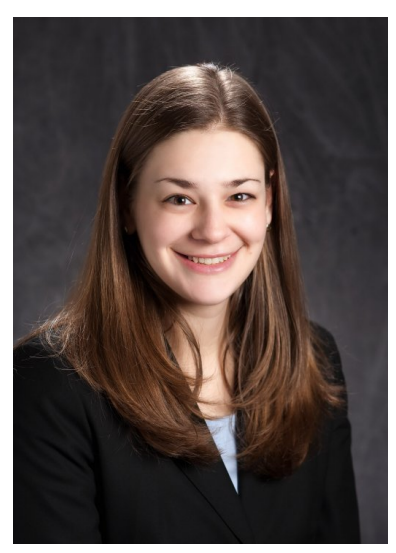

Rebecca Miller is the College Librarian for Science, Life Sciences, and Engineering at Virginia Tech's University Libraries. Previously, she served as the Digital Technologies Librarian at Louisiana State University in Baton Rouge, LA. Rebecca earned her M.S. in Library Science from the University of North Carolina at Chapel Hill, and an undergraduate degree from the College of William \& Mary. Her research interests include the appropriate use of new and emerging technologies in higher education, instructional design, scholarly communication, and the history of libraries and information science. 